\title{
CURRENT CHALLENGES TO THE NON-PROLIFERATION REGIME: IRAN AND NORTH KOREA. A SUMMARY OF PROFESSOR HARNISCH' LECTURE
}

\author{
Dąbrówka SMOLNY, PhD \\ National Defence University, Warsaw, Poland
}

Keywords: Non-Proliferation Regime,: Iran, North Korea, weapons of mass destruction

\section{Introduction}

The purpose of this article is to examine the main arguments presented by prof. Sebastian Harnisch during his lecture titled Current challenges to the NonProliferation Regime: Iran and North Korea on 3 March 2016 at the National Defence University as a part of a series of lectures by prominent political scientists.

Professor Sebastian Harnisch is a German political scientist. Since 2007, he has been at the Heidelberg University Professor of International Relations and Foreign Policy. Previously, he represented the Chair of International Relations of the University of the Bundeswehr Munich. Professor Harnisch studied political science and history at the University of Trier. After a year abroad at Georgetown University, he achieved his Master of Arts in 1993. The German Research Foundation then promoted his research in Seoul (Yonsei University) and Tokyo, and New York (Columbia University), and, in1998, Harnisch received 
his doctorate at the University of Trier with a dissertation on the US -American Korea policy. From 1997 to 2001, he coordinated the Internet project "www. deutsche-aussenpolitik.de". In 2004, he resided in Trier, where he has had a junior professorship since 2003.

As the starting point of his lecture, the question "What will be the future of NATO and what do I consider the future of NATO and our alliance within the European Union?" was posed. In this context, prof. Harnisch decided that it would be appropriate to talk about current issues and international security fears, because alliance partners have not only to care for their immediate neighbourhood, but NATO, as the strongest military alliance and the world as a whole has to consider the wider field of international security proportions and, therefore, he chose a rather eastern topic, thecurrent stability or instability of the non-proliferation regime and the current state crisis within the regime.

His introduction was related to the conflict regarding the North Korean nuclear weapons programme and putting heavier sanctions on North Korea as well as to the recent so called Iranian deal in which Iran promised that its nuclear programme will be peaceful in the future. He underlined he would not talk about nuclear safety, the question of whether all nuclear reactors in our neighbourhood or in Fukushima or elsewhere will be safe, but would talk about the military use of nuclear technology and the NPT, the non-proliferation treaty, which tries to regulate nuclear weapons capacities.

The lecture consisted of three main parts. In the first part of his speech, prof. Harnisch spoke about the non-proliferation and about nuclear weapons technology. This provided the opportunity to learn about the legal aspects of the non-proliferation treaty and, of course, the political dynamics.

Next, he presented the case of Iran or the Islamic Republic of Iran. Some of you may have noticed that recently we had elections in Iran and some of the people with deeper knowledge of Iran argue that the deal pact with the United States and the other prominent members of the Security Council and Germany had an impact on those elections, coming through to direct another election.

In the third part of the lecture, prof. Harnisch spoke about the mechanism, so that we can understand which legal and technical means the international community 
has to stop, limit and then even role-back to the nuclear weapons programme with regard to Iran and appropriate theories.

He introduced the case of North Korea as an example of where the regime didn't quite work recently. There is regular testing of ballistic missile technology on the Korean Peninsula which has consequences for the security of many nations, including the People's Republic of China, the ROK Republic of Korea, and Japan.

\section{The non-proliferation regime}

First of all, according to prof Harnisch, it is important to understand that the nonproliferation regime is an unequal order. It's an estimate for order. It creates two classes of states. One class - states that legitimately holds nuclear weapons. We call those states NWS - nuclear weapons states, and there are 5 of them in the world. They are legitimately holding nuclear weapons.

On the other hand, we have a hundred and eighty nations that abstained from holding nuclear weapons that are non-nuclear weapon states. So, we have an unequal order to create two groups of states with different military capacity. And nuclear weapons, as you all know, are the ultimate weapon. So, when it comes to nuclear defence, Poland, Germany and most north NATO allies rely on the United States for extended deterrence.

This asymmetrical order creates stability only if the two groups are satisfied with the order. Professor Harnisch noted: "It appeared that a couple of states such as India and Iran, from time to time, said "Well, that's not ok". And we have those 5 nuclear weapon states and a hundred and eighty other states. So let's change it. And then the system becomes fluid or more fluid. And North Korea and Iran, as well as Iraq, were the 3 most prominent cases to tick the balance of the system. Therefore, it's important to understand the mechanics of those two crisis worlds."

Also, militarily speaking, there is a quite asymmetric order. On one hand, there's the United States, and on the other, there are lesser nations with much lesser conventional weapons. So, after the intervention of the United States in Iraq and 
the intervention of NATO in Libya, two nations that have tried to get weapons of mass destruction and nuclear weapons sbecame embroiled in war. Those nations who fear that the United States may intervene next on their territory became very concerned about the conventional prominence of the United States. So, for them, weapons of mass destruction, especially nuclear weapons, became more attractive. That was the situation in the mid-2000s.

Sometimes, we think about all our states the same way and the answer to that question is no, it is not because some regime types are more prone and more likely to try to get nuclear weapons than others. They are more attractive to them for several reasons. The research shows that personalised dictatorships, such as the North-Korean dictatorship, is more prone to nuclear proliferation than other regime types. Let's say one-party systems of the autocratic regime type or democratic systems such as presidential systems in Latin America, or parliamentary systems.

Professor Harnisch thinks that "in a true crisis, the international community, in different ways, effectively addressed the nuclear threat (...) so the response stabilised this asymmetric system of the non-proliferation regime. But, in both cases - in the case of Iran and in the case of North Korea - we can see that nuclear stability does not go hand in hand with conventional stability. In political science terms, we call this the paradox sequel effect, the stability-instability paradox. So we have the signal of deterred situation on nuclear level that grows preventional instability along the way because one of the partners may be attracted to conventional conflict."

Subsequently, prof. Harnisch presented information on the process of acquiring nuclear weapon. There are two ways to go to nuclear weapons (fig. 1). One way is by extracting a certain isotope of uranium from natural uranium to enrich uranium 235 to a certain degree and then to keep an amount of more or less 25 kilograms of uranium 235. The nuclear explosive device or dirty bomb does not come along with a nuclear chain reaction, so no key ring, no great explosion, but of course you get a little radiation. So, in order to create a nuclear weapon, you have to create a chain reaction and then it's done if you explode a conventional device and, therefore, set in motion these 25 kilograms of enriched uranium. This is the route that Iran has pursued since 1985 - uranium enrichment. 


\section{Nuclear Weapons: Uranium + PU production}

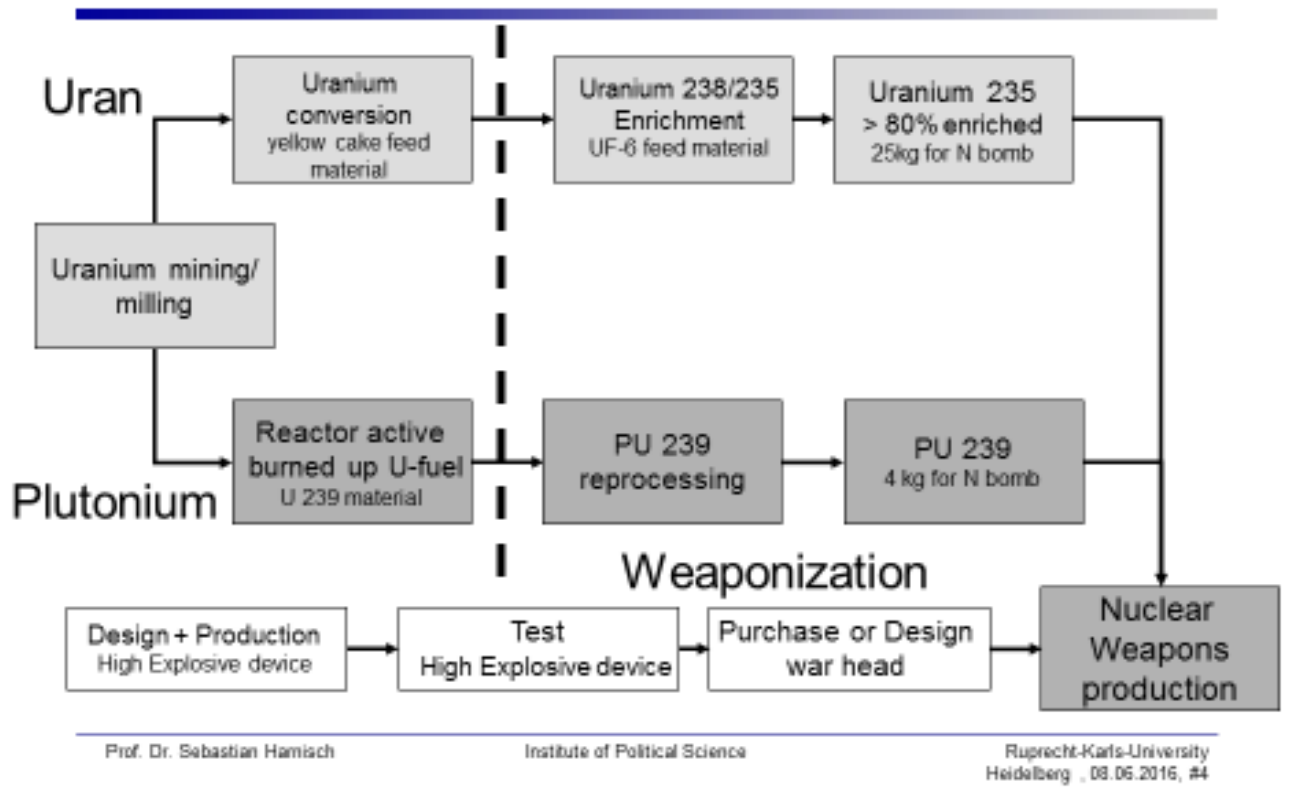

Source: S. Harnisch

Fig. 1. A process of Uranium and Plutonium production

The second way is to use another material - plutonium and to re-process that plutonium, to purify that plutonium. Much lesser amounts of nuclear material are needed to build a device and then it is important in terms of the capacity how heavy that warhead can be or maybe how stable the re-entry that we will call the antiballistic missile is. The plutonium was the road North Korea took first.

As prof. Harnisch noted, the non-proliferation regime is an unequal order. "These are the five nuclear weapon states: Russia, the US, France, the UK and China. There are outer states that have new nuclear weapons, but not under the non-proliferation treaty and there are about 185 nations who don't have those capacities. In order to stabilise security relations between those nations, there are 2 mechanisms. Security among nuclear weapons states is created by occurrence or by co-action - if you shoot first, you die second. We call it mutually assured distraction. Any nation that has nuclear weapons knows that if it uses nuclear weapons it will die second. Because all nations try to have this second strike capacity," he said. The Professor added: "On the other hand, when it comes to the 
non-nuclear weapons states, how can they trust that other nations to not develop nuclear weapons capacity. Why does Poland trust Germany, because technically Germany is capable of building a nuclear weapon probably in six to twelve months. Why does Poland trust that Germany doesn't do so? Well, the answer to that question is you can trust, but you have to verify. And there is an intricate system of verification so that Poland can trust Germany not to build them, build up those capacities. We have IAEA and European safeguard standards that tell Poland that Germany is not the one. And vice versa, because Poland could, or Turkey could, or Saudi Arabia could, or Japan could, or South Korea could build them if there was no verification that they didn't do so."

Now, the security situation is stable, but why should those non-nuclear weapon states trust nuclear weapon states not to detect them? The answer the treaty gives is one side promises non-proliferation - these are the nuclear weapon states - and the other side gets something for it. The treaty requires the nuclear weapon states to disarm, so they have to reduce the threat over time - article 6 of the NPT requires the nuclear weapon states to do so and most nations who are not even capable of building a nuclear industry get nuclear cooperation for peaceful use. There are wealth applications for nuclear technology, for example in medicine. If you want to do a scan of a body often, you use radiation from radiative sources. In order to stabilise this system, this system has an inbuilt interpretation mechanism. It's called the IAEA safeguard system which tells nations what is legitimate behaviour and what is illegitimate behaviour. It has a sanction mechanism. If one nation thinks it can do things other nations consider illegitimate, they can call upon the UN Security Council to find a resolution to it through sanctions or other means. This is what regularly happens.

Does it really stabilise the order? In 1963, President Kennedy estimated that 35 nations would have nuclear weapons by 1975." Professor Harnisch noted that Kennedy "was fortunately wrong, because when you look at the number of nuclear weapons programmes and you see Germany here, because German defence minister Franz Josef Straus seriously thought about a German nuclear weapons programme in the late 1950s, Germany decided otherwise to join the nuclear proliferation team in 1970 and, therefore, the number of countries sitting or having nuclear weapons actually declined over the years." 
Empirically, we make that the system somehow work to reduce the number of states that seek nuclear weapons.

At the same time, more and more nations have joined the treaty. There are up to 185 nations who are part of the non-proliferation treaty. And there are only a few states: Cuba, India, Pakistan and Israel, who never made that promise, and to legitimately haul nuclear weapons outside the non-proliferation treaty.

Many people misunderstand that. Why does Israel have nuclear weapons and Iran have no right to nuclear weapons? Israel never promised to never enter the nonproliferation treaty, but Iran did. Iran promised never to build nuclear weapons and the question is do they want to be out of the treaty and find that everyone would know that they want to go.

The only member missing from the treaty is North Korea. North Korea declared it's withdrawal under article 10 from the treaty on January $10^{\text {th }} 2003$, but all other nations, including Poland, never accepted that withdrawal.

\section{The case of Iran}

Next, prof. Harnisch presented the case of Iran. To begin with, Iran has a lot of reasons to build nuclear weapons. First, Iran has an old culture, a 5000-year history has an expectation of itself as a regional hegemon. It wants to be a big pioneer in the region and tries to underpin this with nuclear weapons.

Secondly, Iran has a lot of territorial disputes, for example with the United Arab Emirates, therefore not everything seems to be fine when it comes to the immediate security of relations with its neighbours.

Thirdly, and probably the most pressing reason, Iran's in a quite unfriendly neighbourhood. India has nuclear weapons, Pakistan has nuclear weapons, Russia has nuclear weapons, and Israel has nuclear weapons. There are also US troops in Afghanistan and Iraq stationed for a very long time who were commercially dominant and, with regard to nuclear weapons, capable right at Iran's border. 
Lastly, Iran has no formal diplomatic relations with two of those nations - the US and Israel. For some time, the US called Iran part of the access of evil, so the intention of the United States to intervene, and to withdraw Iran from this access of evil, was pretty unreal. In the mid-2000s, from a rational perspective, it would have been quite understandable that Iran sought nuclear weapons. Iran was using nuclear power so it thought about nuclear weapons but never pursued this under the Shah of Persia until the Iranian revolution in 1979.

But then, at the height of the conflict with the US, the Iranian regime declared abstinence from civilian and military use of nuclear power for about 4 years. After those 4 years, something important happened for Iran, because in the 1980s Iraq invaded Iran and then, in 1982, 1983, and 1984, they started using chemical weapons against the Iranians. After losing tens of thousands of soldiers to chemical weapons, the Iranians reconsidered their decision not to seek nuclear weapons.

In 1985, Iran contacted a Pakistani nuclear bomb maker and tried to seek a warhead, the technology, some material and they really started the programme. It can be taken for granted that after the international community uncovered their secret weapons programme in 2002 and, in the aftermath of 9/11, they stopped and suspended the programme. There were two agreements in Paris and Sierra Leone when the Iranians froze the programme and did not use the sent refuges to enrich the uranium any more.

In 2005, a new president, Mr Ahmadin Adżab, was elected and Iran resumed the programme and started to produce uranium once again. According to prof. Harnisch "this should show you, with regard to the programme, that Iran switched it on, switched it off, switched it on, and switched it off. They will always make some calculations back and forth." He added: "This record persuaded the international community. $<<$ Well, if they are so shaky on this decision we may influence their behaviour when the price is right $>>$. And that actually was part of the negotiations then going on between the EU, the United States, China and Russia and Iran for a very long time, from 2005 until 2015. The EU and the other nations said <<well, you must stop your nuclear activity at a position where you can't use those technologies for military purposes. You'll have to stop the process. > We call this process the nuclear fuel cycle. The Iranian position was $<<$ No! $>>$ We are a legitimate member of the MPT. We may take this position here 
in order to have a military option. So, in a way, the two positions have a couple of months up to a year in between of nuclear activity and all that adds up to 10 to 12 months difference, all the negotiations from 2006-2007 until 2015 really deal with this."

The solution is named using the acronym JCPOA, or Joint Comprehensive Plan of Action. From July 14 $4^{\text {th }} 2015$, it has 6 parties on the Western side, the five standing members of the Security Council and Germany and Iran. These are formal parties of the agreement. A leading representative of the $\mathrm{EU}$ was part of the negotiation team. The goal is to ensure the peacefulness of the uranium programme in exchange for uplifting sanctions on Iran. And there are quite a few sanctions with a heavy burden on the Iranian economy.

What is important is that JCPOA is not a legally binding instrument. It is a politically binding instrument because the United States felt that the president will never have the capacity to ratify this in Congress.

The Iranian parliament accepted the agreement and the IAA certified in December that, with regard to the past Iranian behaviour, the IAA, as an institution, is not satisfied with the record of the Iranians.

"There was heavy opposition from Israel and Saudi Arabia" - said prof. Harnisch - "because Saudi Arabia said $<<$ Well, if Iran gests out of the sanction business, they will become the regional rebel to us and we don't want it $>>$. And Israel, for understandable reasons, is very sceptical with regard to future Iranian behaviour."

In order to know whether the Iranians will build nuclear weapon in the future, we need to know what kind of capacity they have and will have in the future. The agreement limits the enrichment level in terms of percentages and, because Iran had a certain amount of weaponisable uranium, they had to reduce that amount in order to satisfy international expectations. And, last but not least, there is a clearcut stop power limit on how much nuclear material Iran can hold for the next 15 years. It will not be able to produce plutonium 239 in the same way as before, therefore it has no fine proliferation risk any more. They also pledged that they will never test nuclear weapons, but that's not a technical but a political issue. On the other hand, the IAA got almost everything it wanted in terms of verification. It is the most controlled member of the non-proliferation treaty. There is a clear 
timeline with regard to when the sanctions will be lifted. The last sanctions will be lifted between now and 15 years into the future. So, it is a very long term commitment.

\section{The case of North Korea}

Professor Harnisch continued his lecture describing the case of North Korea: "We right now expect North Korea to have between 6 and up to 16 nuclear warheads of the equivalent of nuclear material. So why did this happen? I think it's pretty clear form the historical record that North Korea started its civilian nuclear programme after the United States threatened intervention with nuclear weapons in the Korean War and after the Cuba crisis, because the North Koreans thought the Soviet Union would not fulfil its commitment. So, with the help of the Soviet Union, they started with their first reactor. The next push came in the 70s. They started a programme which could be used for military purposes and that pushed the North Koreans into deeper weaponisation."

By the end of 2003, it was almost certain that North Korea had the amount of weaponisable nuclear material for one or two bombs. In between, an agreement with JCPOA for North Korea was negotiated. It is called the great agreement that traded lifting up sanctions for weaponisation for nuclear strength on North Korea's part. There was an international organisation called KPEDO that was created to organise this. Actually, in 2003, KPEDO failed and the result was that North Korea steadily built up its nuclear material out of the plutonium programme.

In the meantime, North Korea has had 4 tests and the estimate is that it lost about 1 or 2 warheads equivalent of nuclear material through those tests. But, in 2006, there was also an agreement that North Korea disgarded parts of its plutonium reactor so it never realised the upper - eco looms of these rim bars. They stopped between 8 and 10 nuclear warheads equivalent of material.

The Security Council sanctioned North Korea steadily from 2006 on and heavily over those tests and over those ballistic missile tests. What is more important is that, in 2005, the international community learned that North Korea was very often on and off the proliferation network, together with three other states: 
Syria, Libya and Iran. They created mostly domestic missile technology and even missiles, of all parts - technology, testing and so forth, but also missiles. Israel put out a nuclear facility in Syria on 6nSeptember 2007 which was built by North Korea and Syria who also engaged in nuclear co-operation.

"When it comes to the security situation of NATO, it is important to know where the ballistic missiles and the nuclear material come from, that potentially threaten your nation or your neighbour," said prof. Harnisch. He added: "The argument is North Korea, Iran, Syria and Libya were part of that creation. Libya was taken out. Iran is taken out now. Syria is taken out also. There are only parts of the proliferation network which are still around" (fig. 2).

\section{A DPRK centered Proliferation network?}

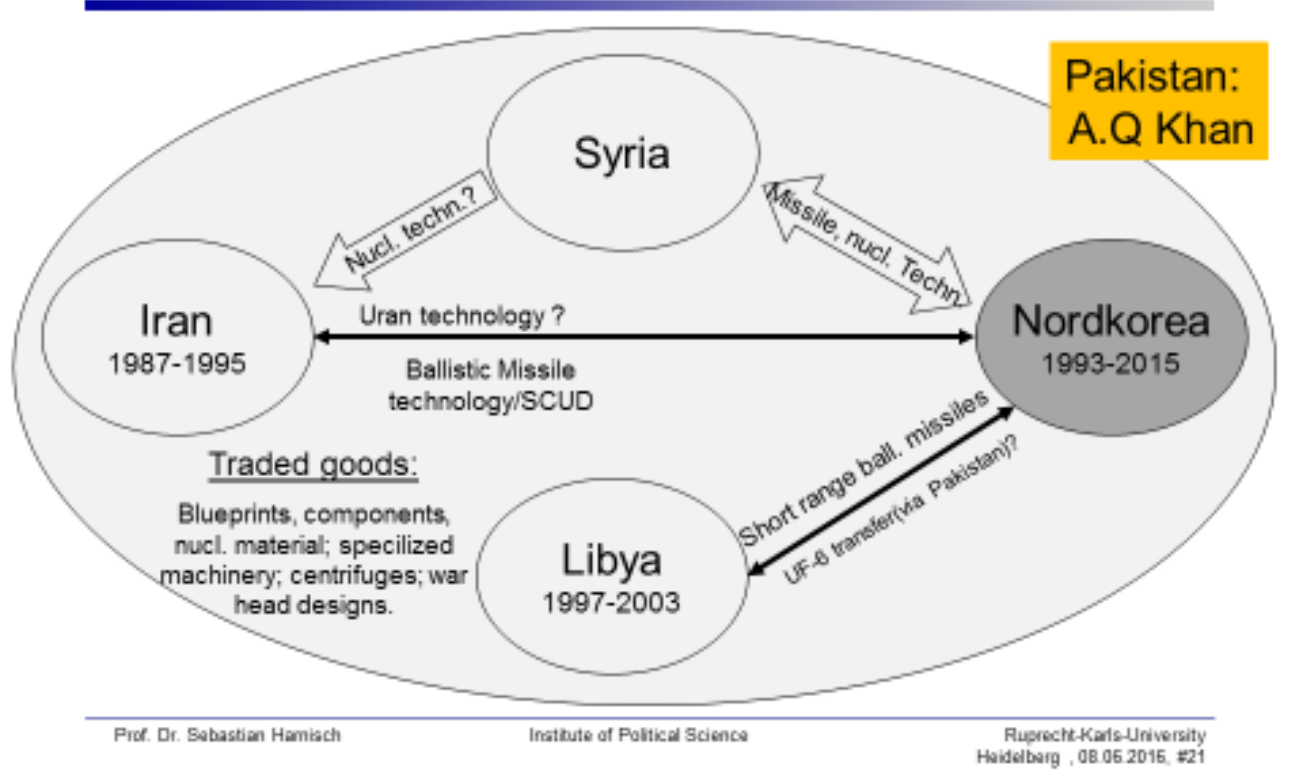

Source: S. Harnisch.

\section{Fig. 2. Proliferation network}

On 2 March 2016 the Security Council put out Security Council Resolution 2217 after the $4^{\text {th }}$ nuclear test on January $6^{\text {th }}$ this year. It is the harshest sanctioning resolution yet, because it cuts off North Korea from the import of crude oil and jet oil, which could be significant for military use. It prohibits the import of coal and minerals from the DPRK and that's a major source of income for the DPRK. 43\% of their export gains come from mineral exporting. It requires the search of all DPRK ships worldwide for 
any contraband, for anything forbidden. It again black-lists more military entities and institutions in North Korea. It shows you that China, who is the "big brother" and the only whole military ally of North Korea, is getting impatient with its "little brother" when it comes to those military nuclear weapon tests.

The question of what North Korea can do or what we expect that they can do with reference to the future remains. In that respect, prof. Harnisch presented possible scenarios (fig. 3). Key low-end estimates, with a base line of 2015 to 2020, are that North Korea, if they proceed all the way on their current road, are that they will have 20 nuclear weapons. That doesn't mean that the 20 nuclear weapons are mounted on intercontinental ballistic missile firing 13,000 kilometres into the continental United States. "That's very unlikely to happen, they don't have this capacity. They don't have attested intercontinental ballistic missiles. What they do have right now is the range of 300 kilometres. The next step is a range of 1,300 kilometres and it will cover Japan, all of South Korea, but will not reach USA forces" he notied.

\section{Delivery System Projections: Three Nuclear Forces for 2020}

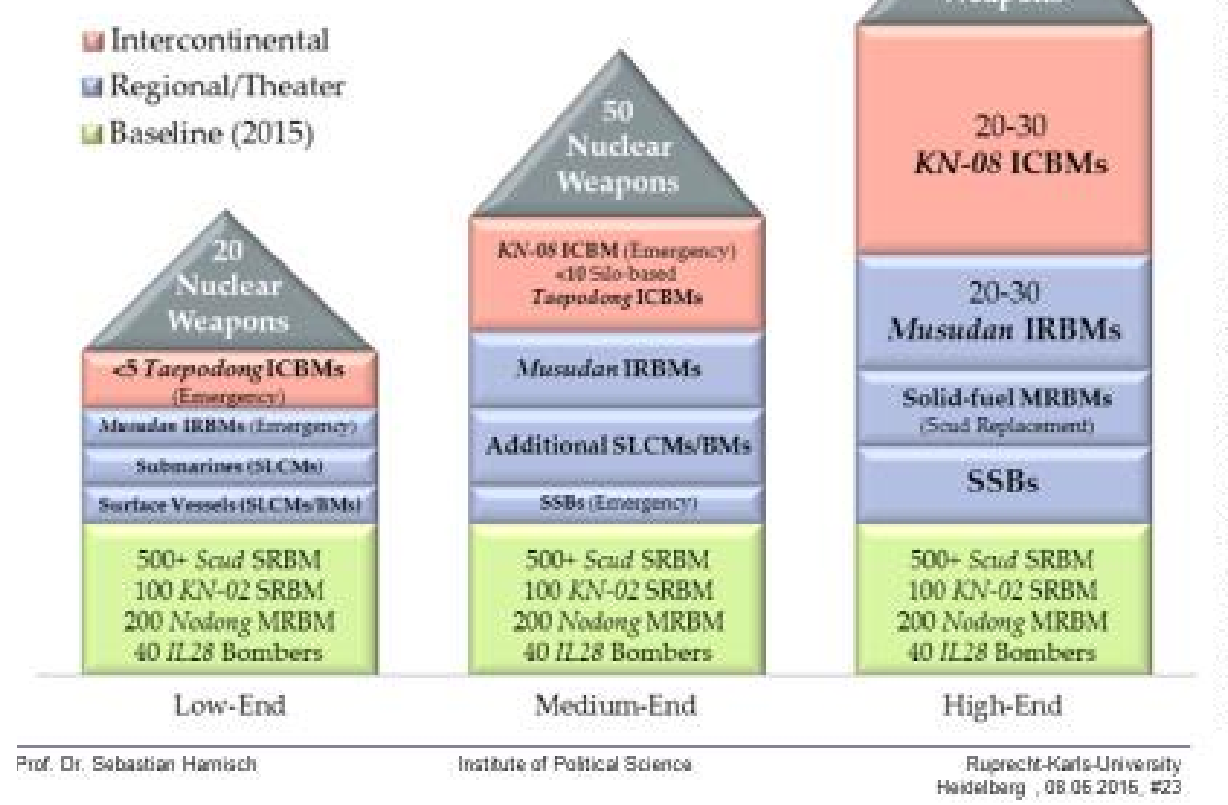

100

Nuclear

Weapons

20-30

$\mathrm{N}$-08 ICBMs

20-30

Musudan IRBMs

Solid-fuel MRBMs

SSBs

$500+$ Srud SRBM

$100 \mathrm{KN}-02$ SRBM

Nodong MRBM

IL 28 Bombers

High-End

Source: S. Harnisch.

Fig. 3. Scenarios of nuclear forces development in North Korea 
The mid-scenario is 50 nuclear weapons, depending on how many of their reactors will go round next year. They will create 15 nuclear warheads and the high-end is 100 nuclear weapons. Why is it important? A nation that has 20 nuclear weapons has beyond a second-strike capacity. Militarily that's the lower end and the nation would not trade warheads to Iran or any other nation willing to pay for them if it has that low a number. But the likelihood that they trade what they have increases the more they have, because then the commercial attractiveness of some of those weapons increases.

Professor Harnisch compared the differences between the true situation and defects for the regime: "North Korea today is a fine state of China. And it is dependent upon trading threats and benefits with China in order to secure itself. If it strays too far ahead of China, China may rule in and put the regime under pressure. And China has the capacity to do so. But the nuclear destabilising effect of North Korea's behaviour is very limited to north-east Asia. Because the United States can extend deterrence, neither South Korea nor Japan have started to think seriously about nuclear weapons. And, obviously, China has an interest to prevent that from happening. Right? Because then it will face three nuclear weapons states, not only the United States."

Professor Harnisch argues that, although North Korea became a nuclear weapon state, the system has accommodated North Korea, and Japan and South Korea are now very tipsy when it comes to the North-Korean threat. On the nuclear level, the system is relatively stable and balanced, but on the conventional level, SouthKorean and Japanese actions start to have effects on the Chinese culture in the region, and also on the US posture in the region.

With regard to Iran, Iran acts as an independent civilian actor not dependent on China or any other nation. It pledged for this nuclear-option in order to underpin its regional posture. So, extended deterrence in the region or similar mechanisms do not work as well in order to contain the threat animating from Iran as they do in north-east Asia. 


\section{Conclusion}

According to prof. Harnisch, although the NPT as a system works and contains the threat that Iran has become a nuclear weapon state, it did not manage to limit the conventional destabilising effect of Iran coming into the world community and potentially earning a lot of money through the lifting of sanctions. "Although North Korea went back, the effect was not as bad as it could have been because of the extended deterrence of the conventional destabilising effect is still there. So, not everything is good." Prof Harnisch concluded. He also added that: "On the other hand, Iran worked much better. We have a deal to scramble, it has a better than even chance to survive even the US conventional elections, but, nevertheless, although the nuclear threat is limited now, we have more or less an open regional situation between Iran and Saudi Arabia., as nations in the Middle East with regard to Yemen, with regard to Syria, with regard to the support for terrorist organisations by those two nations. So, I think it is safe to say that, while the non-proliferation system is still working, it has a destabilising effect on the conventional situation in those two critical regions." 